\title{
Digital Learning Objects in Nursing Consultation: Technology Assessment by Undergraduate Students
}

\author{
DeniseTolfo Silveira ${ }^{1}$ \\ Vanessa Menezes Catalan² \\ Agnes Ludwig Neutzling ${ }^{3}$ \\ Luísa Helena Machado Martinato ${ }^{4}$
}

This study followed the teaching-learning process about the nursing consultation, based on digital learning objects developed through the active Problem Based Learning method. The goals were to evaluate the digital learning objects about nursing consultation, develop cognitive skills on the subject using problem based learning and identify the students' opinions on the use of technology. This is an exploratory and descriptive study with a quantitative approach. The sample consisted of 71 students in the sixth period of the nursing program at the Federal University of Rio Grande do Sul. The data was collected through a questionnaire to evaluate the learning objects. The results showed positive agreement (58\%) on the content, usability and didactics of the proposed computer-mediated activity regarding the nursing consultation. The application of materials to the students is considered positive.

Descriptors: Educational Technology; Education, Nursing; Problem-Based Learning; Nursing.

\footnotetext{
${ }^{1}$ RN, Ph.D. in Sciences, Adjunct Professor, Escola de Enfermagem, Universidade Federal do Rio Grande do Sul, RS, Brazil. E-mail: dtolfo@enf.ufrgs.br.

2 RN, Master's Student, Escola de Enfermagem, Universidade Federal do Rio Grande do Sul, RS, Brazil. E-mail: nessacatalan@yahoo.com.br.

${ }^{3}$ Nursing Undergraduate Student, Escola de Enfermagem, Universidade Federal do Rio Grande do Sul, RS, Brazil. E-mail: ati.ludwig@gmail.com.

${ }^{4}$ Physioterapy Undergraduate Student, Escola Superior de Educação Física, Universidade Federal do Rio Grande do Sul, RS, Brazil. E-mail: lu.martinato@gmail.com.
} 


\title{
Objetos educacionais na consulta de enfermagem: avaliação da tecnologia por estudantes de graduação
}

Este estudo acompanhou o processo ensino-aprendizagem da consulta de enfermagem com apoio de objetos educacionais digitais, por meio da metodologia ativa Problem Based Learning. Os objetivos foram avaliar os objetos educacionais digitais sobre consulta de enfermagem, desenvolver habilidades cognitivas do tema, utilizando aprendizagem baseada em problemas, e identificar as opiniões dos estudantes quanto ao uso da tecnologia. Trata-se de estudo exploratório descritivo, com abordagem quantitativa, cuja amostra foi composta por 71 estudantes da sexta etapa do curso de enfermagem da Universidade Federal do Rio Grande do Sul. A coleta de dados ocorreu por meio da aplicação de questionários para avaliar os objetos de aprendizagem. Os resultados apontam concordância positiva (58\%) quanto ao conteúdo, usabilidade e didática da atividade proposta sobre consulta de enfermagem, mediada por computador. Considerase positivo a aplicação dos materiais junto aos alunos.

Descritores: Tecnologia Educacional; Educação em Enfermagem; Aprendizagem Baseada em Problemas; Enfermagem.

\section{Objetos educacionales en la consulta de enfermería: evaluación de la tecnología por estudiantes de graduación}

\begin{abstract}
Este estudio acompañó el proceso enseñanza-aprendizaje de la consulta de enfermería con apoyo de objetos educacionales digitales por medio de la metodología activa Problem Based Learning. Los objetivos fueron evaluar los objetos educacionales digitales sobre consulta de enfermería, desarrollar habilidades cognitivas del tema utilizando aprendizajes basados en problemas e identificar las opiniones de los estudiantes en cuanto al uso de la tecnología. Se trata de un estudio exploratorio descriptivo con abordaje cuantitativo cuya muestra fue compuesta por 71 estudiantes de la sexta etapa del curso de enfermería de la Universidad Federal del Rio Grande del Sur. La recolección de datos se realizó por medio de la aplicación de cuestionarios para evaluar los objetos de aprendizaje. Los resultados apuntan concordancia positiva ( $58 \%$ ) en cuanto al contenido, usabilidad y didáctica de la actividad propuesta sobre consulta de enfermería mediada por computador. Se consideró positiva la aplicación de los materiales junto a los alumnos.
\end{abstract}

Descriptores: Tecnología Educacional; Educación en Enfermería; Aprendizaje Basado en Problemas; Enfermería.

\section{Introduction}

Based on the Diretrizes e Bases da Educação Nacional e da Graduação em Enfermagem [Guidelines and Foundations for National Education and Undergraduate Nursing Education] ${ }^{(1-2)}$, technologymediated health strategies are considered to modify the way relations occur in education and health. These strategies permit professional to use computers as yet another instrument to construct knowledge, develop skills and support research and recycling. The use of informatics and available resources are in accordance with an educative proposal in the pedagogical process, based on collaborative and interdisciplinary teaching methods(3). Hence, it prepares nursing professionals to face the challenges technology imposes for clinical decision-making, quality management and adequate care determination.

In nursing, higher education institutions regularly offer the computer-mediated teaching-learning process, as it increasingly occurs as one of the aspects the students expect when they start an undergraduate 
program. Research groups investigate technology use, educational practices, support for students and results, with a view to finding best practices in online nursing education. Thus, a correlation was demonstrated between educative practice used in online courses and connectivity and satisfaction as results of the process ${ }^{(4)}$.

When supported by active methods, the educative practices in undergraduate nursing teaching computer technologies enhance tend to gain efficacy through interactivity, collective knowledge production and observance of distinguished learning times and spaces $^{(5)}$. The most used active methods in health include problematization and PBL - Problem Based Learning. In problematization, based on real situations, the subject (student) goes through phases, reflecting on and exercising practice to establish practical conscience $^{(6)}$. In PBL, the student mobilizes pertinent and adequate reflections, seeking creative solutions based on problems or situations that provoke doubts and concerns with a strong practical motivation and cognitive stimulus $^{(7)}$. The importance of putting in practice an active learning method when making available digital materials in nursing is the differential information and communication technologies offer in comparison with traditional classroom practices ${ }^{(8-9)}$.

The importance of a pedagogical framework, not only when the material is conceived, but also when it is applied to students, was demonstrated through the experience of the Virtual Teaching Laboratory - Nursing at the School of Nursing of the Federal University of Rio Grande do Sul (UFRGS), when it produced learning objects in nursing fundamentals ${ }^{(9-11)}$.

The creation of learning objects on the nursing consultation, with support from Call 07 offered by the Distance Education Secretary at UFRGS, in 2007, was founded on problem-based learning, in order to problematize the knowledge students find in their daily reality, based on the formulation of hypotheses for integration with contents they are studying in the subject Adult Nursing Care II. Hence, reflection on practice becomes constant during the user's course when exploring the digital learning object. This digital material comprises five learning objects: one object with theoretical contributions, three objects with clinical cases and one quiz with integrative exercises. The materials contain animations and hypertext, presenting situations that simulate the reality found in practical training areas.

Hence, in this study, the researchers intended to follow the teaching-learning process about the nursing consultation with digital learning objects based on $\mathrm{PBL}$, involving students from the sixth period of the undergraduate nursing program. The proposal involved an active pedagogy that joined presential teaching (in an informatics lab and practical training area) with the use of a virtual learning environment, in which the teacher is concerned not with the contents, but essentially with "why" and "how" the student learns(12).

Moreover, this research discusses computersupported nursing teaching, a practice that is little used among students at the college under analysis.

\section{Aims}

The general goal of this research was to assess digital learning objects regarding their relevance in the teaching-learning process about the nursing consultation among sixth-period undergraduate nursing students.

Specific goals were the performance of preliminary tests with the proposed instrument in order to observe agreement, pertinence and priority of data that needed to be collected: training of sixth-period undergraduate nursing students for learning in a virtual environment; identify the students' opinions on the use of technology, the educational practices they experienced, the support students were offered and the achieved results.

\section{Method}

An exploratory and descriptive study with a quantitative approach was carried out. Quantitative studies use reliability and validity instruments, as well as internal and external validity criteria as measures of scientific rigor ${ }^{(13)}$.

The study was carried out at the School of Nursing of the Federal University of Rio Grande do Sul. This research focused on the subject Adult Nursing Care II, offered in the sixth course period, which uses adult and elderly care from a socio-anthropological perspective as a reference framework.

Nursing students from the sixth course period were invited to participate, who were enrolled in the subject, during the second semester of 2008 and the first semester of 2009. The final sample comprised 71 students, 47 in 2008/2 and 24 in 2009/1.

The students participated in the intervention, that is, in theoretical-practical classes on the nursing consultation and access to the objects made available in the virtual learning environment Moodle ${ }^{\circledR}$.

This study involved two phases. In the first, the data collection instrument was submitted to eight 
consultants specialized in informatics and nursing, with a view to analyzing the agreement and pertinence levels and priority of the data that needed to be collected. The instrument is a 22-item questionnaire on the contents, usability and didactics of the digital learning objects, besides questions on the participant's age, gender, informatics knowledge level and activity in the health area. Specialist assessment of the instrument served as a pre-test to determine whether it was formulated clearly, impartially and usefully to provide the necessary information ${ }^{(14)}$.

In the second phase, the definitive questionnaire was applied to the students in order to assess the learning objects. Thus, an intervention was made in which the researchers proposed a course module on the nursing consultation, according to the following timetable:

Activity 1: presentation and making students accustomed to the virtual learning environment (Moodle ${ }^{\circledR}$ );

Activity 2: presentation of work proposal and exploration of five digital learning objects on the nursing consultation;

Activity 3: group, library, teaching and informatics laboratory activities to solve proposed case studies;

Activity 4: nursing consultation practices in training areas during the semester;

Activity 5: integrative seminar on the nursing consultation, based on the solution of the case studies.

During the first meeting with the students, the project was presented and they were invited to participate in the research, without any connection with their course grades, and signed the free and informed consent term.

This research phase involved data collection through the questionnaire on technology use, educational practices experiences, support offered to students and achieved results. At the end of the semester, all participants were invited to answer the questionnaire and assess activities in quantitative terms.

Hence, the respondents received the questionnaire, whose header clarified the study goal, the voluntary nature of their participation, the possibility to interrupt their participation at any time, besides guaranteeing participants' anonymity. The return of the completed instrument was considered as acceptance to participate in the study. Data will be kept for five years and then destroyed.

Through the Virtual Learning Environment Moodle ${ }^{\circledR}$, with its resources and tools (through reports, answers to questionnaires, participation in activities in the general environment), specific analyses could be obtained to assess the learning process on the nursing consultation. The use of this platform also collaborated in the solution phase of the case studies the students were proposed, as teachers could make available material for students to integrate the contents presented in the learning objects with what current literature offers, besides offering students the chance, through a forum, to discuss their doubts and and suggestions with colleagues and teachers.

Quantitative data from the questionnaires were processed in SPSS ${ }^{\circledR}$. Information was analyzed through descriptive statistics, used central tendency (mean, median) and the respective dispersion measures (standard deviation and percentiles), as well as (absolute and relative) frequencies.

Authorization for this project was obtained from the Research Commission at the School of Nursing of the Federal University of Rio Grande do Sul and the Research Ethics Committee at the Institution (No 2007871).

This research received funding from the Brazilian Scientific and Technological Development Council (CNPq), through a Scientific Initiation grant to be of help in the activities. Computers at the Virtual Teaching Laboratory of the School of Nursing were used to construct the research database. The researchers paid for all other material expenses.

\section{Results}

The final study sample comprised 47 students from the second semester of 2008 and 24 from the first semester of 2009, totaling 71 subjects enrolled in the subject Adult Nursing Care II, who answered the proposed questionnaire. Sixty (84.5\%) students were female and 11 (15.5\%) male. Ages ranged between 20 and 36 years, with a stronger concentration between 20 and 24 years (59.1\%). As for the knowledge level on informatics, most participants considered their level intermediary $(63.3 \%), 19(26.7 \%)$ basic and only six (8.4\%) advanced.

On the item regarding work in the health area, $32(45 \%)$ interviewees answered "yes", that they are already working in the area, 10 (14\%) of whom identified themselves as nursing technicians, one (1.4\%) as an administrative aid, one $(1.4 \%)$ as an infirmary soldier and the remainder as trainees or grantees.

In response to the items assessed through the questionnaire, the answer "fully disagrees" was considered the minimum and "fully agrees" the maximum agreement level.

The results appoint positive agreement (58\%) on the contents, usability and didactics of the proposed activity on the nursing consultation (Figure 1). 


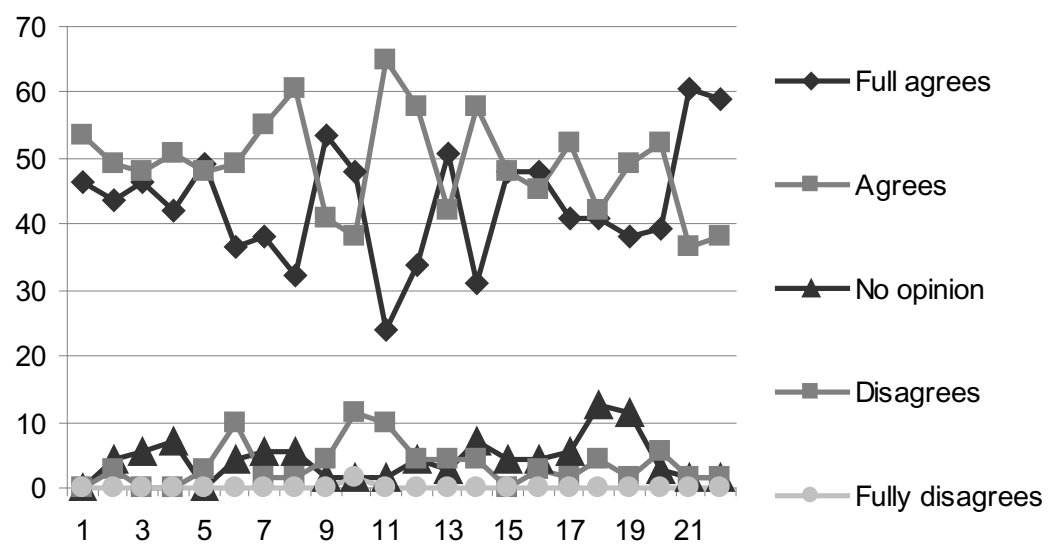

Figure 1 - Contents, Usability and Didactics

Very little variability or dispersion was found for the assessed variables, which turns percentiles or medians hardly representative. Therefore, the positive agreement (answers fully agrees or agrees) percentages for most items are shown.

As observed in Figure 2, about the contents variable, $49.3 \%$ of participating students fully agreed that the digital material presents precise and updated information; most students agreed that the learning objects are "clear and concise" (53.5\%), "is relevant" (49.3\%), "demonstrates baseline concept" (47.9\%), "describes concepts well" (50.7\%), "includes appropriate quantity of material" (49.3\%), "summarizes the concept well" (55\%) and "presents high quality (writing and editing)" (60.6\%).
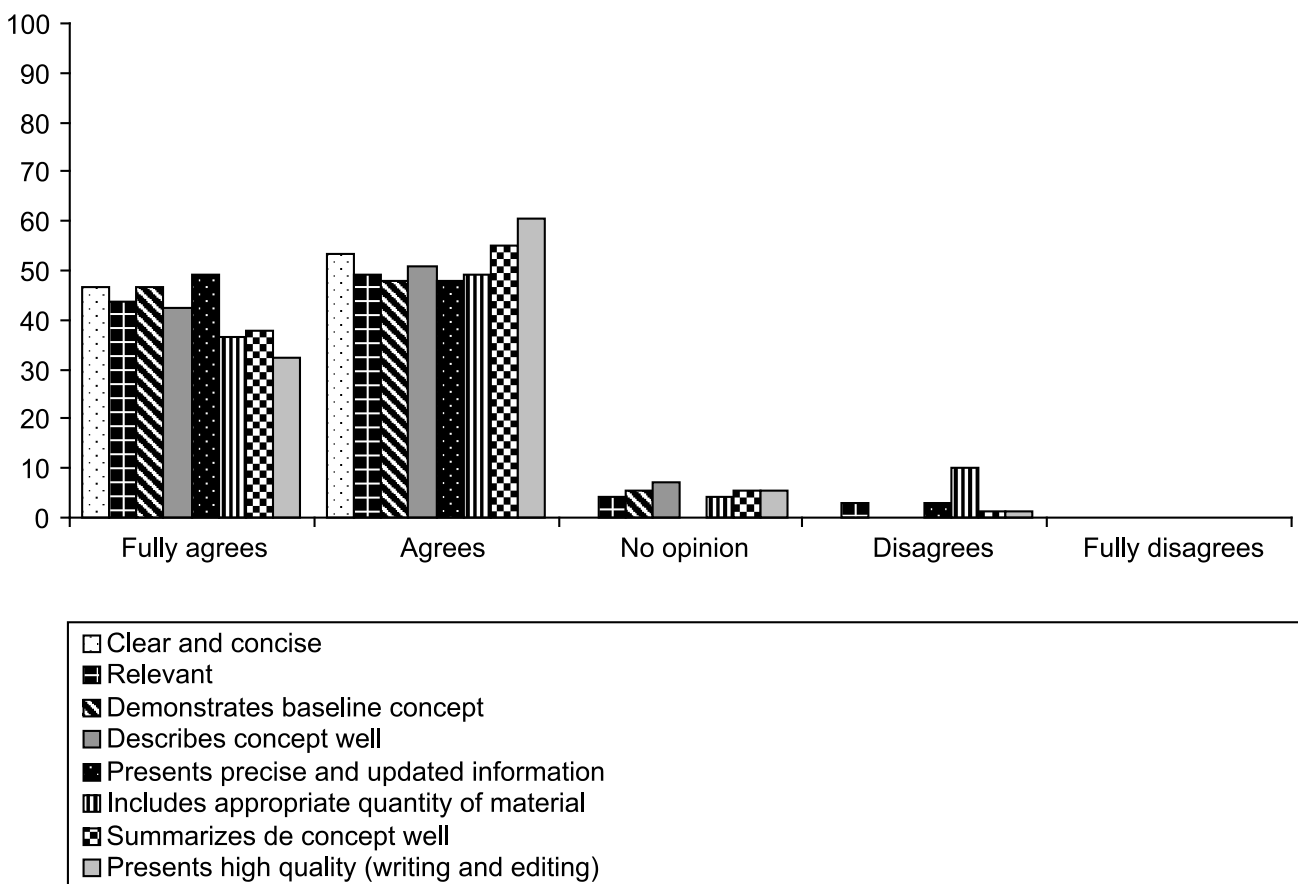

Figure 2 - Students' assessment on "content" variable items

When questioned about the contents, the majority fully agreed that it is easy to use (53.5\%), offers clear instructions (47.9\%) and is interactive, and also agreed that the instrument is involving/motivating (64.8\%), visually attractive (57.8\%) and has a high-quality graphical design (57.8\%) (Figure 3 ). 

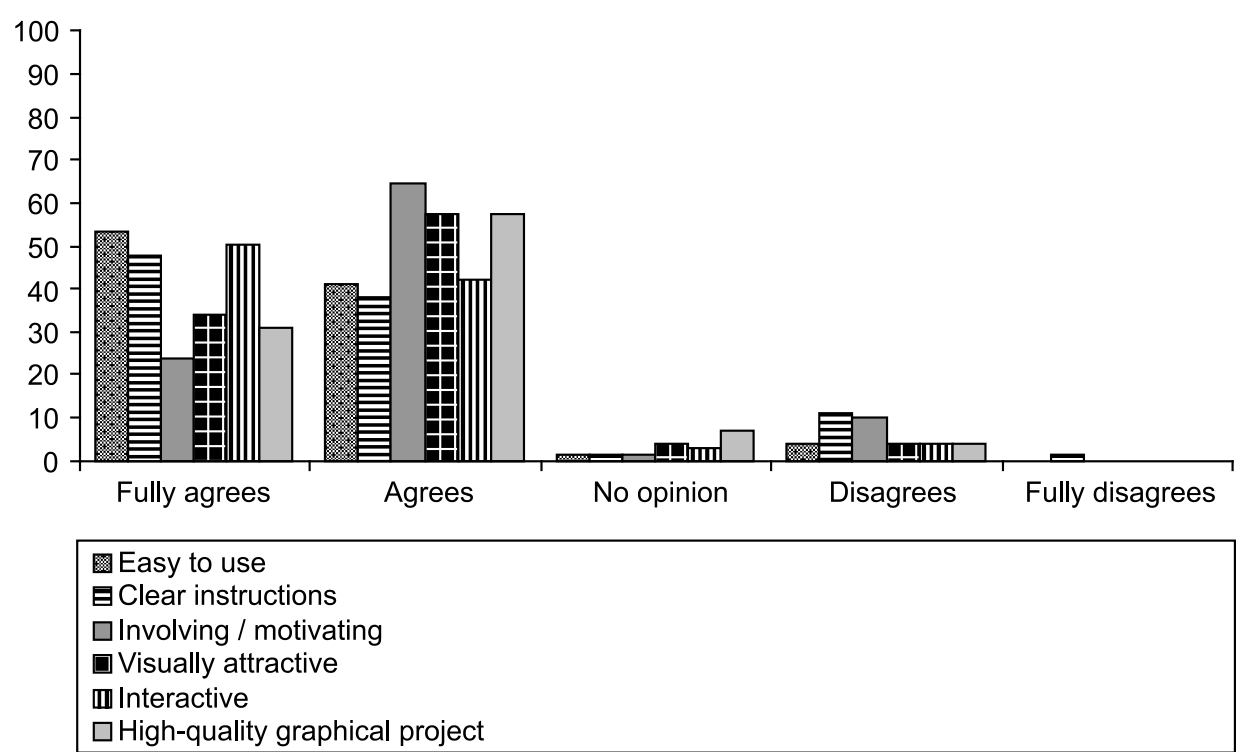

Figure 3 - Students' assessment on "usability" variable items

Regarding usability aspects (Figure 4), most research subjects fully agreed when asked whether the instrument "identifies previous knowledge" (47.9\%), whether the "clinical cases presented contributed to reinforce learning" (60.6\%) and whether the "materials promoted learning" (59.2\%), and also agreed that "concepts are presented in a context" (52.2\%), that it "demonstrates relations between concepts" (42.3\%), that it "progressively reinforces concepts" (49.3\%) and that "multimedia resources (sound, image, video) are complementing the text they refer to" (52.2\%). About identifying learning objectives, $47.9 \%$ fully agreed and another $47.9 \%$ agreed with the item.

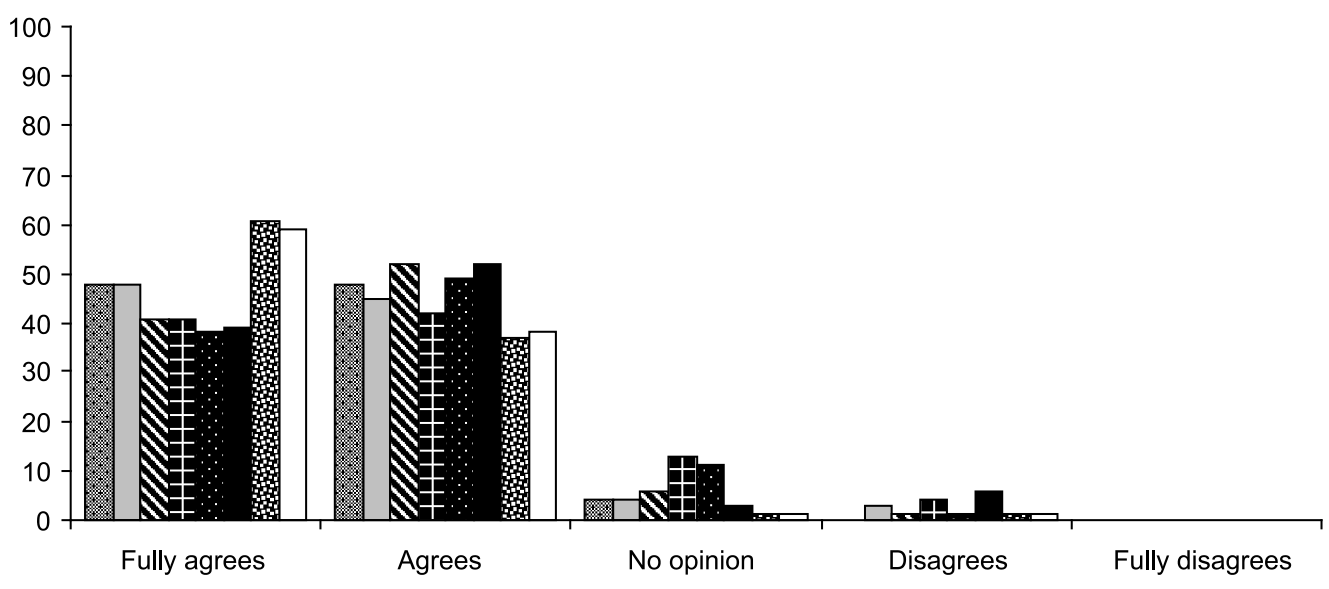

Identifies learning objectives

$\square$ Identifies previous knowledge

$\mathbf{D}$ Presents concepts in a context

$\square$ Demonstrates relations between concepts

a. Progressively reinforces concepts

Multimedia resources are complementing the text they refer to

国 Clinical cases presented contributed to reinforce learning

$\square$ Materials enhanced learning

Figure 4 - Students' assessment on "didactics" variable items 


\section{Discussion}

One significant finding refers to the relation between the assessment form of the items "provides clear instructions" and "multimedia resources are complementing the text they refer to" and the variable "working in the health area", suggesting that instructions can be improved for the sake of a better understanding among students who do not work in that area.

The use of any technology is directly associated with the user's skills and competency, with a view to a possible benefit ${ }^{(15)}$. This distances any view on the deification of technology, which alone does not promote learning, but merely provides information, requiring teachers and students' involvement to construct knowledge. Thus, the learning object enhances the learning process and, departing from the simulation, permits users to develop, synthesize and apply their knowledge in a replica of an actual experience.

In a systematic review on how simulation can be effective as a teaching and learning method in comparison with other educational strategies, it was evidenced that simulation can also offer some advantages over other teaching methods, depending on the context and method(16). Besides, the PBL characteristics used in the construction of the digital material are in accordance with the goals of technological education, including: multi-sensory, simulation of reality, student collaboration, studentcentered learning and problem solving. This discussion has indicated that PBL is applicable to technological education in several contexts(17).

The students' higher satisfaction scores with their learning experience confirm other research results ${ }^{(9,16,18)}$. The methodological innovation the learning object offers can justify this evidence, as it stimulates cognitive and cooperation skills, as opposed to the teachers' training, centered on teaching methods that emphasize individual technical skills. In view of this traditional training, students cannot recognize alternative teaching styles that can also satisfy their learning needs ${ }^{(17)}$.

The digital learning object under analysis was conceived to improve the way clinical skills are taught to undergraduate nursing students. The assessment suggests that students are favorable to self-management and to flexible aspects of this teaching method, used to complement instead of replace presential classes ${ }^{(19-20)}$.

Results of the students' assessment show that the learning objects in Moodle satisfied the users, are adequate, lead to precise or expected results, interact with the specified systems, are in agreement with standards, conventions or rules and access safety is a strong point, in compliance with ISO/ICE 9126(21).
About the program's adequacy, the menus allow users to freely navigate through the software, in a nonlinear and flexible structure. In line with other studies, the researchers believe that the users' possibility to go wherever they want inside the software increases their interest and stimulates learning(3,22-24).

As the health system is constantly changing, nursing teaching faces many challenges. Therefore, the nursing curriculum should be dynamical and include information and interactive technology management, facilitating the students' involvement with a view to promoting critical thinking and improving clinical assessment ${ }^{(25)}$.

\section{Final considerations}

The researchers consider that the study goals were achieved. The application of the materials to sixth-period students in the undergraduate nursing program is considered positive for skills development in the study areas and in the construction of a set of resources for shared used in distance education and health education.

Initial concerns with turning the subject into a positive experience that constructs knowledge and exchanges served as a trigger that permitted the conception and execution of that part of the project that has already become real. The researchers hope to exchange experiences on its use with a view to significant learning development for all stakeholders in the process.

One possible interpretation of the obtained results is the identification that it was important not only to adopt technologies, but also to adequately incorporate teaching methods. And, in this case, PBL offers a range of relevant resources for technological education, as a result of which the project described here has been developed.

In view of the findings and considering that the goal of nursing education is to prepare people for professional practices, educators should commit to and promote information use. Moreover, through communication and information technologies, teachers can favor their use among students as tools for their professional practices and choices, with a view to an early and virtual experience of the selected profession and with a view to their adaption to the needs technology entails.

Discussion is needed, however, with a view to raising educators' awareness that the choice of this technology is intimately related with the pedagogical proposal they intend to develop, as who determines its possible users in education are the teachers, with their conceptions on what it means to teach and learn.

Besides, this way of producing digital materials is characterized as a viable alternative at a public university, due to its decentralization and low cost of the necessary technological resources. 


\section{References}

1. Presidência da República (BR). Lei no 9394 de 20 dez 1996. Estabelece Diretrizes e Bases da Educação Nacional. Diário Oficial da União, Seção 1(248):27833-41.

2. Conselho Nacional de Educação (BR). Diretrizes Curriculares Nacionais para o curso de graduação em Enfermagem. C.N.E./ C.E.S. no 3, de 7 nov 2001. Diário Oficial da União, Seção1, p. 37; 2001.

3. Aguiar RV, Cassiani SHB. Desenvolvimento e avaliação de ambiente virtual de aprendizagem em curso profissionalizante de enfermagem. Rev. Latino-Am. Enfermagem. [periódico na Internet]. 2007 Dez [acesso 22 jun 2010 ; 15(6): 1086-91. Disponível em: http://www.scielo.br/scielo.php?script=sci_ arttext\&pid=S0104-11692007000600005\&lng=pt. doi: 10.1590/S0104-11692007000600005.

4. Billings DM, Skiba DJ, Connors HR. Best practices in web-based courses: generational differences across undergraduate and graduate nursing students. J Prof Nurs. 2005;21(2):126-33.

5. Lashley M. Teaching health assessment in the virtual classroom. J Nurs Educ. 2005; 8(44):348-50.

6. Berbel NAN. A problematização e a aprendizagem baseada em problemas: diferentes termos ou diferentes caminhos?. Interface (Botucatu) [periódico na Internet]. fev 1998 [acesso 23 jun 2010]; 2(2):139-54. Disponível em: http:// www.scielo.br/scielo.php?script=sci_arttext\&pid=S141432831998000100008\&lng=pt. doi: 10.1590/S141432831998000100008.

7. Sá $H$, organizador. Aprendizagem baseada em problemas: anatomia de uma nova abordagem educacional. Fortaleza: Escola de Saúde Pública; São Paulo: Hucitec; 2001. p. 49-78.

8. Silva APSS. Punção venosa: avaliando o processo de ensinoaprendizagem de acadêmicos de enfermagem com objeto educacional digital. [Monografia - trabalho de conclusão de curso]. Porto Alegre (RS): Escola de Enfermagem da UFRGS; 2006.

9. Cogo ALP, Pedro ENR, Silveira DT, Silva APSS da, Alves RHK, Catalan VM. Desenvolvimento e utilização de objetos educacionais digitais no ensino de enfermagem. Rev. LatinoAm. Enfermagem [periódico na Internet]. 2007 Ago [acesso 22 jun 2010] ; 15(4): 699-701. Disponível em: http:// www.scielo.br/scielo.php?script=sci_arttext\&pid=S0104$11692007000400028 \&$ lng $=$ pt. doi: $10.1590 /$ S010411692007000400028 .

10. Cogo ALP, Silveira DT, Catalan VM. Objetos de aprendizagem digitais como ferramenta de apoio na educação em enfermagem. Anais do $10^{\circ}$ Congresso Brasileiro de Informática em Saúde; 2006; Florianópolis; 2006. p. 368-9.

11. Cogo ALP, Pedro ENR, Silva APSS, Schatkoski AM, Catalan VM, Alves RHK. Objetos educacionais digitais sobre oxigenoterapia: avaliação por docentes de um curso de graduação. Rev Esc Enferm USP. 2009; 43(2):295-9.
12. Cyrino EG, Pereira MLT. Trabalhando com estratégias de ensino-aprendizado por descoberta na área da saúde: problematização e a aprendizagem baseada em problemas. Cad Saúde Pública. 2004; 20(3):780-8.

13. Lobiondo-Wood G, Haber J. Pesquisa em enfermagem: métodos, avaliação crítica e utilização. 4. ed. Rio de Janeiro (RJ): Guanabara Koogan; 2001.

14. Polit DF, Beck CT, Hungler BP. Fundamentos de pesquisa em enfermagem: métodos, avaliação e utilização. 5 ed. Porto Alegre (RS): Artes Médicas; 2004.

15. Correa $\mathrm{CHW}$. Comunidades virtuais gerando identidades na sociedade em rede. Ciberlegenda 2004; (13). [acesso $18 \mathrm{fev}$ 2010]. Disponível em: http://www.uff.br/mestcii/cyntia1.htm

16. Cant RP, Cooper SJ. Simulation-based learning in nurse education: systematic review. J Adv Nurs. 2010; 66(1):3-15.

17. Williams PJ, Iglesias J, Barak, M. Problem based learning: application to technology education in three countries. Int J Technol Des Educ. 2008;18:319-35.

18. Jeffries PR, Rizzolo MA. Designing and Implementing Models for the Innovative Use of Simulation to Teach Nursing Care of ill Adults and Children: A National, Multi-Site, Multi-Method Study. New York (USA): National League for Nursing; 2006.

19. Kelly M, Lyng C, Mcgrath M, Cannon G. A multi-method study to determine the effectiveness of, and student attitudes to, online instructional videos for teaching clinical nursing skills. Nurse Educ Today. 2009;29:292-300.

20. Paranhos VD, Mendes MMR. Currículo por competência e metodologia ativa: percepção de estudantes de enfermagem. Rev. Latino-Am. Enfermagem. [periódico na Internet]. 2010 Fev [acesso 22 jun 2010]; 18(1):109-15. Disponível em: http://www.scielo.br/scielo.php?script=sci_arttext\&pid=S010411692010000100017\&lng=pt. doi: 10.1590/S010411692010000100017.

21. ISO/IEC 9126. Software product evaluation - Quality characteristics and guidelines for their use. 1991. [Cited 2008 Jun 20]. Available from: http://www.usabilitynet.org/tools/r_ international.htm\#9126-1.

22. Valaitis R K, Sword W A, Jones B, Hodges A. Problem-based learning online: perceptions of health science students. Adv Health Sci Educ. 2005; 10:231-52.

23. Caetano KC, Peres HHC. Metodologia para estruturação de hipertexto aplicado ao ensino de enfermagem. Acta Paul Enferm. jun 2007; 20(2):175-9.

24. Fonseca LMM, Leite AM, Mello DF de, Dalri MCB, Scochi CGS. Semiotécnica e semiologia do recém-nascido pré-termo: avaliação de um software educacional. Acta Paul Enferm. 2008; 21(4):543-8.

25. Jensen $R$, Meyer $L$, Sternberger $C$. Three technological enhancements in nursing education: Informatics instruction, personal response systems, and human patient simulation. Nurse Educ Pract. 2009; 9:86-90.

Received: Mar. .t $^{2010}$

Accepted: Ago. 25 2010 